INOBIS: Jurnal Inovasi Bisnis dan Manajemen Indonesia

Volume 2, Nomor 1, Desember 2018

Ratna Tri Hardaningtyas

\title{
Persepsi Masyarakat Terhadap Penggunaan Transportasi Online (GRAB) di Malang
}

\author{
Ratna Tri Hardaningtyas \\ FEB-Universitas Islam Malang \\ ratnatyas@unisma.ac.id
}

\begin{abstract}
Abstrak
Penelitian ini bertujuan untuk mengetahui persepsi masyarakat terhadap penggunaan transportasi online di Malang (GRAB). Populasi dalam penelitian ini adalah konsumen yang menggunakan pelayanan dari transportasi online (GRAB). Teknik pengambilan sampel menggunakan metode indepth interview dengan melakukan wawancara secara mendalam kepada informan yang berjumlah 10 orang dilatar belakangi usia dan profesi yang berbeda. Teknik analisa yang digunakan adalah metode deskriptif kualitatif yang berguna untuk memberikan fakta dan data. Hasil penelitian menunjukkan bahwa persepsi masyarakat terhadap penggunaan transportasi online (GRAB) berpengaruh signifikan dan positif. Persepsi masyarakat terbukti bahwa dapat mempengaruhi pandangan terhadap transportasi online. Dikarenakan tansportasi online melakukan pelayanan terhadap masyarakat, maka mulai dari kinerja maupun atribut transportasi dapat mempengaruhi persepsi masyarakat. Baik atau buruknya persepsi yang ada di masyarakat terhadap transportasi online, bergantung pada kualitas pelayanan itu sendiri. Kesuksesan sebuah pelayanan dibidang jasa ditunjang oleh kinerja para pengemudi transportasi online pada saat memberikan pelayanan terhadap masyarakat. Pelayanan yang diberikan kepada masyarakat akan sangat mempengaruhi persepsi masyarakat sebagai konsumen baik itu persepsi buruk maupun persepsi yang baik terhadap transportasi online.
\end{abstract}

Kata kunci: GRAB, penggunaan transportasi online, dan persepsi masyarakat.

\section{Pendahuluan}

Pada tahun 2012 dikabarkan ada sekelompok teman yang sedang menikmati teh bersama. Seperti warga Asia Tenggara pada umumnya, mereka mulai mengeluh tentang sulitnya mendapat taksi. Namun setelah itu, mereka melakukan sesuatu yang tidak biasa. Mereka memutuskan untuk menyelesaikan masalah ini. Mereka merupakan inisiator Grab (yang saat itu dikenal sebagai MyTeksi). Dalam yang waktu singkat, tujuan sederhana mereka bertransformasi menjadi sesuatu yang lebih besar - membuat Asia Tenggara jadi tempat yang lebih baik.

Grab telah hadir di 6 negara di seluruh Asia Tenggara. Dan banyak orang yang menggunakan layanan mereka setiap harinya. Tapi kita lebih dari sekedar "angka" bagi mereka. Seperti kita, mereka juga orang-orang Malaysia, Singapura, Indonesia, Thailand, Vietnam, dan Filipina. Kita adalah tetangga, teman dan keluarga, untuk membawa kita semua maju bersama.

Kondisi lalu lintas yang padat dan kesibukan masyarakat di Malang tidak memungkiri mereka untuk menggunakan jasa transportasi. Untuk menghindari kemacetan di Malang kerap membuat masyarakat enggan untuk mengendarai kendaraan mereka. Pemilihan alternatif jasa transportasi yang mampu menghindari kemacetan serta harga yang ramah adalah transportasi roda dua (ojek), kini telah hadir ojek online (GRAB), GRAB adalah perusahaan berjiwa sosial 
INOBIS: Jurnal Inovasi Bisnis dan Manajemen Indonesia

Volume 2, Nomor 1, Desember 2018

Ratna Tri Hardaningtyas

yang bergerak dibidang jasa dengan menggunakan transportasi roda dua serta penggunaan aplikasi dalam pemesanannya.

Pengemudi ojek direkrut dengan cara dilatih, serta dibekali jaket, helm dan smartphone yang berguna melihat pemesanan serta menghitung harga berdasarkan jarak. Masyarakat di Malang sangat senang dengan adanya transportasi online seperti GRAB, karena pemesanan yang mudah menggunakan aplikasi melalui smartphone, harga yang terjangkau serta transparant. Ojek online (GRAB) menghadirkan berbagai macam layanan yang ada pada aplikasi mereka sehingga masyarakat sangat puas karena ojek tidak hanya untuk mengantarkan mereka pulang pergi tetapi juga bisa mengantarkan makanan, dan barang dengan tarif yang tergolong terjangkau.

Saat ini masyarakat sangat menyukai ponsel (smartphone), mulai dari browsing, bermain game online bahkan berbelanja pun bisa dilakukan secara online melalui ponsel. Tidak hanya berbelanja online saja yang bisa dilakukan melalui ponsel, tetapi memesan layanan jasa pun bisa dilakukan secara online. Semakin menjamurnya penggunaan internet dimasyarakat membuat pebisnis menciptakan peluang yang telah marak dikalangan masyarakat dengan menggabungkan jasa transportasi dengan internet, dimana akan menjadi terobosan baru dalam transportasi.

Kemajuan teknologi dibidang transportasi menjadikan para pebisnis bersaing menciptakan inovasi terbaru serta melihat dari fenomena yang terjadi dimasyarakat bahwa saat ini internet sangat berpengaruh dalam kehidupan masyarakat. Maraknya pengguna smartphone, baik android maupun ios menjadikan masyarakat bergantung pada handphone serta internet. Peluang tersebut yang menjadikan pendiri ojek online (GRAB) menghadirkan ojek berbasis online. Fenomena transportasi online saat ini sedang hangat diperbincangkan, karena pemesanan berbasis aplikasi yang mudah di download oleh pengguna smartphone baik android maupun ios. Pemesanan melalui aplikasi yang mudah membuat ojek online diterima dengan cepat dikalangan masyarakat, serta berbagai macam pilihan layanan yang diberikan sehingga mampu memenuhi kebutuhan masyarakat dalam bidang jasa.

Berdiri pada tahun 2012 sebagai social entrepreneurship inovatif untuk mendorong perubahan sektor transportasi agar dapat beroperasi secara profesional. Saat ini GRAB telah bermitra dengan lebih dari 10.000 pengendara ojek di Jakarta, Surabaya, Bandung, Makasar, Malang hingga kota-kota lainnya.

Ojek online di Malang sendiri saat ini yang menjadi best friendly transportation adalah GRAB, dinaungi oleh perusahaan yang jelas, kebersihan dan kemanan dalam berkendara diberikan oleh GRAB dengan memfasilitasi konsumen helm, jas hujan, serta penutup kepala agar rambut konsumen tetap bersih dan tejaga karena helm yang digunakan oleh banyak konsumen. Harga yang transparant yang dimiliki GRAB lewat aplikasi pemesanannya adalah salah satu kunci utama yang membuat ojek online diminati oleh masyarakat. Serta yang membuat GRAB berbeda dengan ojek lainnya adalah memiliki merk (brand) "GRAB" serta pemilihan warna bernuansa hijau diatribut GRAB, baik dari helm, jaket pengemudi, serta aplikasi, membuat masyarakat akan selalu ingat dibenak mereka bahwa ojek berwarna hijau adalah GRAB.

Pengguna ojek online (GRAB) sendiri bervariasi, mulai anak muda hingga dewasa, baik anak sekolah maupun pekerja kantoran. GRAB mampu mensegmen segala konsumen, serta mempunyai produk jasa yang mudah digunakan dan harganya tergolong bersahabat.

Pelayanan yang ditawarkan GRAB dan diminati di Malang antara lain adalah tidak hanya grab-bike (ojek online) tetapi ada grab-food (layanan antar makanan dan minuman), dan grab-express (layanan antar barang). 
INOBIS: Jurnal Inovasi Bisnis dan Manajemen Indonesia

Volume 2, Nomor 1, Desember 2018

Ratna Tri Hardaningtyas

Grab-bike adalah ojek dengan menggunakan sepeda motor roda dua yang pemesanannya dengan menggunakan sistem aplikasi online, grab-food adalah layanan pemesanan makanan melalui aplikasi GRAB dan akan diantarkan oleh pengendara ojek ke alamat yang dituju lalu setelah pemesanan datang, pembayaran baru dapat dilakukan sesuai dengan harga makanan yang dipesan serta ongkos kirim, grab express adalah layanan antar barang dengan menggunakan sepeda motor roda dua dengan pengambilan barang di alamat pemesan lalau mengantarkannya kepada alamat tujuan penerima barang, biaya ditanggung oleh pemesan.

Untuk GRAB, pemesanan dapat dilakukan dengan mengakses aplikasi GRAB, memasukkan alamat untuk mengetahui biaya penggunaan layanan, serta dapat menggunakan pelayanan "use my location" untuk mengarahkan driver ke tempat anda berada. Setelah mengkonfirmasi pesanan, maka secara otomatis based location akan mencarikan pengendara ojek terdekat dari lokasi pemesan.

Setelah pengendara ojek ditugaskan, pemesan dapat melihat foto pengendara ojek serta nomor telepon, dan dapat langsung melakukan penilaian performance terhadap pengendara secara otomatis yang sudah disediakan didalam aplikasi GRAB. Hal ini yang menjadi faktor utama masyarakat di Malang kerap menggunakan GRAB, pelayanan yang disediakan serta penilaian pengendara, bila pengendara dirasa kurang memuaskan maka dapat melaporkan pada pihak manajemen GRAB dan akan segera ditindak lanjuti atau cukup dengan memasukkan penilaian sejumlah 1 bintang (sangat tidak memuaskan), maka nanti akan diproses oleh pihak manajemen GRAB.

Berdasarkan latar belakang yang telah di uraikan diatas, rumusan masalah yang dapat di kemukakan adalah sebagai berikut: (1) Bagaimana persepsi masyarakat terhadap penggunaan transportasi online (GRAB) di Malang?. Berdasarkan latar belakang dan rumusan masalah diatas, maka tujuan yang ingin dicapai dalam penelitian ini adalah : (1) Penelitian ini bertujuan untuk mengetahui persepsi masyarakat terhadap penggunaan transportasi online (GRAB) di Malang.

Tujuan dari penelitian ini adalah untuk melihat persepsi masyarakat terhadap penggunaan transportasi online (GRAB) di Malang.

\section{Landasan Teori dan Pengembangan}

\subsection{Pemasaran}

Menurut Boyd (2000:4) pemasaran adalah suatu proses yang melibatkan kegiatankegiatan penting yang memungkinkan individu dan perusahaan mendapatkan apa yang mereka butuhkan dan inginkan melalui pertukaran dengan pihak lain. Pemasaran didefenisikan sebagai telaah terhadap aliran produk secara fisik dan ekonomik dari produsen melalui pedagang perantara sampai ke tangan konsumen.

\subsection{Konsep Pemasaran}

Konsep pemasaran adalah sebuah falsafah bisnis yang menyatakan bahwa pemuasan kebutuhan konsumen merupakan syarat ekonomi dan sosial bagi kelangsungan hidup perusahaan. 
INOBIS: Jurnal Inovasi Bisnis dan Manajemen Indonesia

Volume 2, Nomor 1, Desember 2018

Ratna Tri Hardaningtyas

\subsection{Bauran Pemasaran}

Bauran pemasaran menurut Kotler dan Amstrong (2012:92) adalah perangkat pemasaran yang baik yang meliputi produk, penentuan harga, promosi, distribusi, digabungkan untuk menghasilkan respon yang diinginkan pasar sasaran.

\subsection{Jasa}

Jasa adalah suatu tindakan atau kinerja yang ditawarkan oleh salah satu pihak kepada pihak lain. Meskipun proses dapat dikaitkan dengan suatu produk fisik, kinerja pada dasarnya intangible dan biasanya tidak menghasilkan kepemilikan salah satu faktor produksi (Kotler dan Keller, 2009).

\subsection{Karakteristik jasa}

Hal ini sering mengatakan bahwa layanan memiliki karakteristik unik yang membedakan mereka dari barang atau produk yang diproduksi. Empat karakteristik yang paling sering ditemui dalam pelayanan dan membedakan barang secara umum: (a.) tidak Berwujud, jasa bersifat abstrak dan tidak berwujud, berarti bahwa layanan tidak dapat dilihat, dirasakan, terasa atau menyentuh seperti dapat dilihat dari item;(b) heteregonitas, jasa adalah variabel non - standar dan sangat bervariasi. Artinya, karena jasa dalam bentuk kinerja, maka tidak ada manfaat hasil yang sama bahkan jika dilakukan oleh satu orang. Hal ini disebabkan interaksi manusia (karyawan dan pelanggan) dengan semua harapan yang berbeda dan persepsi yang menyertai interaksi tersebut; (c) tidak dapat dipisahkan, jasa umum diproduksi dan dikonsumsi pada saat yang sama, dengan partisipasi konsumen dalam proses. Artinya, konsumen harus berada di tempat jasa yang diminta, sehingga konsumen melihat dan bahkan mengambil bagian dalam proses produksi; (d) tidak tahan lama, jasa mungkin tidak disimpan dalam persediaan. Ini berarti bahwa layanan tidak dapat disimpan, dijual kembali kepada orang lain, atau dikembalikan ke produsen layanan yang ia membeli jasa.

\subsection{Strategi Pemasaran Perusahaan Jasa}

Terdapat tiga tipe pemasaran dalam dunia usaha, antara lain: (a) pemasaran eksternal (external marketing), Strategi pemasaran eksternal ini dikenal dengan 4P (product, price, promotion, place); (b) pemasaran internal (internal marketing) Pemasaran jasa tidak cukup hanya dengan pemasaran ekternal (4P) tetapi harus diikuti pula dengan peningkatan kualitas atau keterampilan para personil yang ada dalam perusahaan. Selain itu, juga harus ada kekompakan atau suatu tim yang tangguh dari personil yang ada dalam perusahaan tersebut, khususnya dalam menghadapi para pelanggan sehingga membawa kesan tersendiri yang meyakinkan pelanggan; (c) pemasaran interaktif (interaktif marketing), Kepuasan konsumen tidak hanya terletak pada mutu jasa, misalnya restorannya yang megah dan makanannya yang bergizi, tetapi juga harus dipadukan dengan melakukan service quality improvement supaya peningkatan pelayanan benar-benar meyakinkan.

\subsection{Pengembangan Produk atau Jasa Baru}

Enam kategori inovasi jasa, yaitu: (a) inovasi utama, pengembangan produk yang ditujukan pasar baru. Kategori ini sangat beresiko namun apabila berhasil dapat memberikan 
INOBIS: Jurnal Inovasi Bisnis dan Manajemen Indonesia

Volume 2, Nomor 1, Desember 2018

Ratna Tri Hardaningtyas

keuntungan yang sangat besar; (b) bisnis startup, cara baru dan inovatif untuk mengetahui kebutuhan terkini dari konsumen dan meningkatkan jangkauan pilihan yang tersedia. Beberapa inovasi dapat mencakup kedua kategori di atas; (c) produk baru untuk pasar yang sedang dilayani. Memungkinkan penyedia jasa menggunakan costumer base sebaik-baiknya dan melakukan penjualan silang (cross sell) produk lain. Perubahan teknologi telah meningkatkan kesempatan untuk inovasi dan kreativitas; (d) perluasan lini produk, menawarkan jasa kepada konsumen dengan variasi yang lebih luas dari pilihan dalam lini jasa yang sudah ada. Hal ini inovasi umum bagi bisnis yang sudah mencapai fase kematangan, yang sudah mempunyai segmen pasar inti yang ingin dipertahan kan; (e) perbaikan produk, memperbaiki tampilan (fitur) dari produk yang sudah ada; (f) perubahan gaya, Pengembangan unsur nyata dari produk jasa, contoh: citra baru perusahaan, seragam baru kasir dan lain-lain.

\subsection{Persepsi}

Melalui persepsi individu dapat menyadari, dapat mengerti tentang keadaan diri individu yang bersangkutan. Persepsi itu merupakan aktivitas yang integrateed, maka seluruh apa yang ada dalam diri individu seperti perasaan, pengalaman, kemampuan berpikir, kerangka acuan dan aspek-aspek lain yang ada dalam diri individu masyarakat akan ikut berperan dalam persepsi tersebut (Walgito, 2000:54).

\subsection{Masyarakat}

Sedangkan yang dimaksud dengan masyarakat adalah sekelompok manusia yang hidup dalam satu kesatuan dalam tatanan sosial masyarakat. Masyarakat adalah setiap kelompok manusia yang telah cukup lama hidup dan bekerja sama sehingga mereka itu dapat mengorganisasikan dirinya dan berpikir tentang dirinya sebagai kesatuan sosial dengan batasbatas tertentu.

\subsection{Persepsi Masyarakat}

Menurut Slameto (2010:102), persepsi adalah proses yang menyangkut masuknya pesan atau informasi kedalam otak manusia, melalui persepsi manusia terus menerus mengadakan hubungan dengan lingkungannya. Hubungan ini dilakukan lewat inderanya, yaitu indera pengelihat, pendengar, peraba, perasa, dan pencium.

\subsection{Ojek Online}

Menurut Peneliti, ojek online adalah transportasi yang menggunakan sepeda motor roda dua dengan dilengkapi aplikasi dalam pemesanannya, sistem pembayaran yang transparant yang telah tersedia dalam aplikasi, layanan use my location yang didukung dalam sistem internet yang memudahkan pengendara mencari lokasi pemesan. Identitas pengendara sangat jelas dapat di lihat didalam aplikasi pemesanan, pemesan tidak perlu repot-repot mencari ojek, hanya membuka aplikasi pemesanan maka akan segera menemukan pengendara ojek.

\subsection{Brand (merek)}

Menurut Bilson $(2001 ; 149)$ Merek adalah nama, tanda, istilah, simbol, desain atau kombinasinya yang ditujukan untuk mengidentifikasi dan mendiferensiasi (membedakan) 
INOBIS: Jurnal Inovasi Bisnis dan Manajemen Indonesia

Volume 2, Nomor 1, Desember 2018

Ratna Tri Hardaningtyas

barang atau layanan suatu penjual dari barang atau layanan penjual lain.

\subsection{Elemen-elemen Brand}

Yang menentukan tingkat kepercayaan konsumen terhadap sebuah brand adalah sebagai berikut: (a) janji yang diberikan sesuai dengan kenyataan walaupun hal ini tidak dinyatakan dengan jelas, tetapi menjadi salah satu faktor utama kesuksesan sebuah brand; (b) memberikan kepribadian tersendiri terhadap pengguna brand. Pengguna mobil BMW akan merasakan lebih elegan dan ekslusif ketimbang pengguna mobil Innova misalnya; (c) usp (unique selling proposition). Munculnya sebuah brand sebagai dasar untuk membedakan perusahaan, produk atau layanannya dengan perusahaan lainnya; (d) dari beberapa pengertian diatas, dapat ditarik kesimpulan mengenai definisi dari Brand (Merek) itu sendiri. Maka, Brand (merek) adalah nama, tanda, istilah, simbol, desain, kata atau kombinasi dari hal-hal tersebut yang ditujukan untuk mengidentifikasi dan membedakan antara produk dan jasa yang satu dengan yang lain.

\subsection{Pemberian Nama Produk (Merek)}

Menurut Kotler (2012 : 101), produsen yang ingin mencantumkan merek pada produknya akan menghadapi beberapa pilihan stategi pemberian nama merek, yaitu: (a) nama merek khusus (individual brand name), yaitu pemberian nama merek yang berbeda bagi tiap item jenis produk; (b) nama kelompok gabungan bagi semua produk (a blanket family name), yaitu pengunaan nama merek yang sama pada semua item dan lini produk; (c) nama kelompok yang terpisah (separate family name), yaitu pemakaian nama merek yang berbeda bagi tiap lini produk; (d) nama perusahaan digabung dengan nama khusus (company trade name combined with individual product names).

\subsection{Elemen - elemen Merk}

Nama, logo, simbol, desain, slogan, dan kemasan. Beberapa kriteria yang harus diperhatikan dalam pemilihan elemen merek: (a) mudah di ingat, artinya elemen merek yang dipilih hendaknya yang mudah diingat, dikenali, dan disebut atau diucapkan. Simbol, logo, nama yang digunakan hendaknya menarik, unik sehingga menarik perhatian masyarakat untuk diingat dan dikonsumsi; (b) memiliki makna, artinya elemen merek hendaknya mengandung sebuah makna maupun penjelasan atau deskripsi dari produk; (c) menarik dan lucu, pendekatan lain untuk menarik perhatian konsumen adalah dengan variasi elemen merek yang unik, lucu, pemilihan elemen yang kaya akan visualisasi dan imajinasi. Dalam hal ini yang ditonjolkan adalah desain yang menarik dan lucu; (d) fleksibel, artinya elemen merek dapat dimengerti dan tetap dapat diterima oleh daerah atau pasar, bahkan budaya lain. Nama yang digunakan pun tidaklah terlalu sulit untuk diterjemahkan. Seringkali pemilihan elemen merek mudah diingat oleh masyarakat lokal, namun sangatlah sulit dimengerti oleh masyarakat lain. Hal ini tentunya akan menghambat produsen untuk masuk dalam pasar yang baru; (e) legal, artinya brand elemen tersebut sah menurut hukum dan undang-undang yang berlaku, sehingga berada di bawah perlindungan hukum. 
INOBIS: Jurnal Inovasi Bisnis dan Manajemen Indonesia

Volume 2, Nomor 1, Desember 2018

Ratna Tri Hardaningtyas

\subsection{Strategi Merk}

Menururt Aaker (1996), mengatakan bahwa merek yang kuat adalah yang memiliki posisi kuat. Pembentukan posisi yang kuat dimulai dengan menganalisis situasi untuk mengetahui posisi merek-merek pesaing dan posisi merek saat ini (merek yang sudah diluncurkan).

\subsection{Ekuitas Merk}

Ekuitas merek (brand equity) adalah nilai tambah yang diberikan pada produk dan jasa. Ekuitas merek berbasis-pelanggan (customer-based brand equity) adalah pengaruh diferensial yang dimiliki pengetahuan merek atas respons konsumen terhadap pemasaran merek tersebut. Ekuitas merek adalah seperangkat aset dan liabilitas merek yang berkaitan dengan suatu merek, nama dan simbolnya, yang menambah atau mengurangi nilai yang diberikan oleh suatu barang atau jasa kepada perusahaan atau pelanggan.

\subsection{Brand Awareness}

Yang dimaksudkan dengan brand awareness adalah kemampuan calon pembeli atau konsumen untuk mengenali maupun mengingat sebuah merek. Dalam hal ini tentunya bisa meliputi nama, gambar atau logo, serta slogan tertentu yang digunakan para pelaku pasar untuk mempromosikan produk-produknya.

\subsection{Penelitian Terdahulu}

Penelitian tentang "Pengaruh Persepsi Kemudahan Terhadap Niat Beli Ulang Dengan Persepsi Kegunaan Sebagai Variabel Intervening (studi Pada Pengguna Layanan Aplikasi GO-JEK di Surabaya)" (Wahyuningtyas, 2016). "Pengaruh Kualitas Layanan dan Harga Terhadap Kepuasan Pelanggan Jasa Transportasi Ojek Online (studi Pada Konsumen Gojek di Surabaya)" (Nafisa, 2015).

\section{Metode Penelitian}

\subsection{Jenis Penelitian}

Jenis penelitian penelitian ini menggunakan metode penelitian kualitatif. Menurut Sugiyono (2010:15), metode penelitian kualitatif merupakan metode penelitian yang berlandaskan pada filsafat positivisme, digunakan untuk meneliti pada kondisi obyek yang alamiah, (sebagai lawannya adalah eksperimen) dimana peneliti adalah sebagai instrumen kunci, pengambilan sampel sumber data dilakukan secara purposive dan snowball, teknik pengumpulan dengan trianggulasi, analisis data bersifat induktif atau kualitatif, dan hasil penelitian kualitatif lebih menekan makna dari pada generalisasi.

Selain definisi-definisi diatas, ada definisi penelitian kualitatif lainnya seperti yang dikemukakan oleh Creswell (2010:152), mengatakan bahwa sebagai seorang peneliti kualitatif harus benar-benar matang dalam melakukan identifikasi partisipan dan lokasi penelitian sebagai pondasi awal penelitian yang akan dilakukan. Jelas definisi ini menggambarkan bahwa penelitian kualitatif mengutamakan latar alamiah, agar hasilnya dapat digunakan untuk menafsirkan fenomena, dan metode yang biasanya digunakan adalah wawancara, 
INOBIS: Jurnal Inovasi Bisnis dan Manajemen Indonesia

Volume 2, Nomor 1, Desember 2018

Ratna Tri Hardaningtyas

pengamatan, dan pemanfaatan dokumen.

\subsection{Gambaran dari populasi penelitian}

Setiap penelitian ilmiah pasti akan dihadapkan dengan masalah sumber data yang disebut dengan populasi dan sampel. Menurut buku metode penelitian oleh Sugiyono (2012:119) populasi adalah wilayah generalisasi yang terdiri atas obyek atau subyek yang mempunyai kualitas dan karakteristik tertentu yang ditetapkan oleh peneliti untuk dipelajari dan kemudian ditarik kesimpulannya. Informan dalam penelitian ini adalah Masyarakat di Malang.

\subsection{Teknik Pengumpulan Data}

\subsubsection{Jenis Data}

Terkait dengan jenis data ini, penulis menggunakan: (1) wawancara mendalam (in-depth Interview), data yang diteliti berkaitan dengan subjek yaitu berupa karakteristik dan tanggapan dari masyarakat di Malang mengenai persepsi mereka mengenai ojek online (GRAB) dikalangan masyarakat Malang yang digunakan sebagai informan dalam penelitian ini. Metode interview juga bisa disebut dengan metode wawancara dengan cara mengajukan pertanyaan kepada informan secara bertatap muka, dari wawancara tersebut akan diperoleh hasil dari tanya jawab oleh informan yang nantinya akan menjadi data dalam penelitian; (2) pengamatan (observation), observation atau pengamatan adalah setiap kegiatan untuk melakukan pengukuran, dalam arti sempit, pengamatan yang dilakukan dengan menggunakan panca indera dengan tidak mengajukan pertanyaan-pertanyaan. Peneliti melakukan observasi dengan cara terjun langsung ke lokasi melakukan pengamatan, serta melibatkan diri secara langsung dengan cara mengamati objek penelitian agar mendapatkan data yang akurat; (3) dokumentasi, dokumentasi merupakan pengumpulan data yang tidak langsung ditujukan kepada subyek penelitian. Dokumen dapat dibedakan menjadi dua, dokumen primer yang merupakan tulisan langsung oleh seseorang yang mengalami peristiwa yang bersangkutan. Kedua, dokumen sekunder yang merupakan tulisan dari cerita orang lain. Penulis melengkapi penelitian dengan mendokumentasikan ke dalam foto pada saat wawancara dengan responden, serta merekam suara responden menggunakan handphone merek LG dengan aplikasi voice recorder dan menyalin hasil rekaman tersebut kedalam tulisan.

\subsubsection{Sumber Data}

Data primer, yaitu data yang diperoleh secara langsung dari informan yang menjadi sasaran penelitian. Data ini didapat dari hasil wawancara dengan acuan yang terdapat pada lembar pertanyaan yang diberikan kepada informan. Wawancara yang dilakukan secara face to face terhadap informan agar informasi dapat tersalurkan secara rinci dan jelas.

\subsubsection{Teknik Pengumpulan Data}

Berdasarkan sumber data yang digunakan dalam penelitian ini, maka penulis menggunakan pengumpulan data dengan cara wawancara dan memberikan lembar pertanyaan kepada masyarakat di Malang. 
INOBIS: Jurnal Inovasi Bisnis dan Manajemen Indonesia

Volume 2, Nomor 1, Desember 2018

Ratna Tri Hardaningtyas

\subsection{Teknik Analisis Data}

Data-data yang telah diperoleh peneliti, selanjutnya akan dianalisis menggunakan teknik analisis interaktif Miles dan Huberman Punch (Pawito, 2008:104), yang menyebutkan bahwa teknik ini terdiri dari tiga komponen yaitu: (a) reduksi data (data reduction), yang mempunyai tiga tahap : (i) tahap pertama yaitu editing, pengelompokkan dan peringkasan data, (ii) tahap kedua yaitu penyusunan catatan-catatan tentang berbagai hal yang berkaitan dengan unit analisis, sehingga peneliti dapat menemukan tema-tema dan pola-pola data (iii) tahap ketiga yaitu konseptualisasi tema-tema dan pola-pola data; (b) penyajian data (display), yaitu pengorganisasian data dengan menjalin atau mengaitkan kelompok data yang satu dengan kelompok data yang lain, sehingga seluruh data dapat dianalisis dalam sebuah kesatuan; (c) penarikan atau pengujian kesimpulan (drawing and verifying conclusion), yaitu pengimplementasian prinsip induktif dengan mempertimbangkan pola-pola data yang ada dan atau kecenderungan dari data display yang telah disusun.

Menurut Sugiyono (2010:88), melakukan analisis adalah pekerjaan yang sulit, memerlukan kerja keras. Analisis memerlukan daya kreatif serta kemampuan intelektual yang tinggi tidak ada cara tertentu yang dapat diikuti untuk mengadakan analisis, sehingga setiap peneliti harus mencari sendiri metode yang dirasakan cocok dengan sifat penelitinya.

\subsection{Satuan Kajian}

Setelah menyatukan kajian yang telah dibahas melalui latar belakang, dapat disimpulkan bahwa persepsi masyarakat terhadap jasa transportasi online telah diterima baik oleh masyarakat di Malang. Meskipun tergolong jasa baru, GRAB mampu mencuri perhatian masyarakat di Malang melalui merek serta logo yang melekat dibenak warga Malang. Peneliti menyimpulkan bahwa satuan kajian menghasilkan dampak positif terhadap penelitian ini. Dikarenakan respon dari masyarakat di Malang yang menerima GRAB sebagai transportasi baru secara baik, dikaji melalui latar belakang serta didukung adanya jurnal dari peneliti terdahulu.

\subsection{Analisis Deskriptif}

Keakuratan data yang diperoleh dianalisis melalui hasil wawancara, serta analisis historical yang telah berkembang di masyarakat. Masyarakat di Malang sangat tertarik dengan adanya transportasi online, saat ini GRAB yang masih diminati masyarakat di Malang, karena sangat membantu dalam kegiatan sehari-hari mereka, pemesanan yang cepat, promo harga yang transparant. Penggunaan logo serta warna menjadi ciri khas GRAB sehingga sangat melekat dibenak masyarakat Malang bahwa transportasi online adalah GRAB.

\section{Hasil Penelitian dan Pembahasan Gambaran Umum}

\subsection{Subyek Penelitian Karakteristik Responden Berdasarkan Usia}

Karakteristik Informan yang menggunakan transportasi online (GRAB) di Malang berkaitan dengan usia mereka dapat digambarkan pada Tabel 1 : 
INOBIS: Jurnal Inovasi Bisnis dan Manajemen Indonesia Volume 2, Nomor 1, Desember 2018

Ratna Tri Hardaningtyas

Tabel 1

Karakteristik Responden Menurut Usia

\begin{tabular}{cc}
\hline Usia & Jumlah (orang) \\
\hline $18-20$ th & 1 \\
$21-30$ th & 6 \\
$31-40$ th & 3 \\
Total & 10 \\
\hline
\end{tabular}

Sumber: data primer diolah, 2018

Berdasarkan data yang didapat dari Tabel.1 menunjukkan gambaran distribusi frekuensi berkaitan dengan usia responden yang menggunakan transportasi online di Malang, jumlah responden terbanyak adalah yang berusia antara 21-30 tahun sebanyak 6 orang. Kemudian diikuti oleh informan yang berusia antara 31-40 tahun sebanyak 3 orang. Sedangkan sisanya berusia antara 18-20 tahun sebanyak 1 orang. Hasil ini mengindikasikan bahwa konsumen yang menggunakan transportasi online di Malang kebanyakan berusia dewasa yaitu 21-30 tahun, hal ini dimungkinkan karena pada usia tersebut, merupakan usia produktif.

\subsection{Karakteristik Informan Berkaitan dengan Pekerjaan}

Karakteristik informan yang menggunakan transportasi online di Malang berkaitan dengan pekerjaan mereka dapat digambarkan pada Tabel 2 :

Tabel 2

Karakteristik Responden Menurut Pekerjaan

\begin{tabular}{cc}
\hline \hline Pekerjaan & Jumlah (orang) \\
\hline Pelajar atau Mahasiswa & 2 \\
Swasta atau & 6 \\
Wiraswasta & \\
Pegawai Negeri & - \\
Ibu Rumah Tangga & 2 \\
Total & 10 \\
\hline
\end{tabular}

Sumber : data primer diolah, 2018

Berdasarkan data yang didapat dari Tabel 2 menunjukkan gambaran distribusi frekuensi berkaitan dengan pekerjaan informan yang menggunakan trasnportasi online di Malang, frekuensi terbanyak adalah informan yang berprofesi sebagai Swasta atau Wiraswasta sebanyak 6 orang. Kemudian di ikuti oleh profesi mahasiswa sebanyak 2 orang serta lainnya yaitu ibu rumah tangga sebanyak 2 orang.

\subsection{Deskriptif Hasil Penelitian}

Analisis data secara deskriptif ini mendeskripsikan hasil analisis terhadap informan dengan cara menguraikan tanggapan dari 10 responden berkaitan denganpersepsi masyarakat terhadap transportasi online di Malang berdasarkan data dari hasil wawancara yang telah dilakukan dimana peneliti menggunakan metode kualitatif dan pendekatan deskriptif. Dalam pembahasan penelitian ini akan menjelaskan, memaparkan, serta menggambarkan data yang 
INOBIS: Jurnal Inovasi Bisnis dan Manajemen Indonesia

Volume 2, Nomor 1, Desember 2018

Ratna Tri Hardaningtyas

telah diperoleh oleh peniliti melalui wawancara secara mendalam (in-depth interview) yang dilakukan kepada para informan. Untuk lebih jelasnya, maka pada bab ini dibagi menjadi dua bagian sistematis dan terarah yaitu sebagai berikut :

1. Deskripsi informan penelitian

2. Pembahasan

\subsection{Deskripsi Informan Penelitian}

\section{Anissa (Icha) 31 tahun, Ibu Rumah tangga}

Informan satu ini memiliki panggilan bernama Ibu Icha. Menggunakan transportasi online (GRAB) sejak tahun 2016, saat ditemui dikediamannya yang berlokasi di JL. Karya Timur, Malang. Ibu Icha pertama kali mengetahui transportasi online GRAB dari media elektronik dan saudaranya.

Pelayanan GRAB yang sering Ibu Icha gunakan adalah grab-bike, grab-food, dan grabexpress., alasan beliau sering menggunakan pelayanan tersebut karena sangat tepat waktu dan praktis.

Ibu icha memaparkan bahwa persepsinya terhadap transportasi online (GRAB) adalah beliau sangat senang, karena memudahkan untuk menjalankan aktivitasnya. Kerap berpergian bersama buah hatinya yang berumur 2 tahun, memutuskan Ibu Icha untuk menggunakan layanan GRAB karena praktis, mudah, cepat dan aman. Ibu Icha adalah pengguna smartphone android, karena pemesanannya melalui aplikasi melalui smartphone nya. Menurut Ibu Icha transportasi online sangat mudah, pada saat beliau membutuhkan transportasi hanya dengan satu aplikasi saja yaitu GRAB, di dalam aplikasi tersebut terdapat banyak layanan. Bila ingin mendapatkan layanan antar jemput motor, maka hanya mengklik layanan grab-bike dan melakukan pemesanan. Serta di dalam aplikasi tersebut terdapat aplikasi grab-food dan grabexpress yang menjadi favorit Ibu Icha.

Menurut Ibu Icha, kinerja pengemudi GRAB pada saat beliau menggunakan pelayanannya adalah sangat baik, karena pengemudi GRAB sangat berhati-hati dalam mengemudikan kendaraannya. Ibu Icha memaparkan, bahwa beliau kerap menggunakan pelayanan GRAB bersama buah hatinya yang berumur 2 tahun, dan sejauh ini aman dan tidak ugal-ugalan bila berada di jalan raya. Kelebihan GRAB menurut Ibu Icha terletak pada promo harga yang sangat miring, alasan tersebut yang menjadikan beliau memilih GRAB sebagai transportasi online kegemarannya.

\section{Satria Abdi Pratama, 22 tahun, Mahasiswa Universitas Islam Malang}

Saat ditemui di Universitas Islam Malang, responden berikut ini bernama Satria. Sebagai mahasiswa yang aktif dengan segala kegiatan, beliau juga gemar menggunakan gadget smartphone. Rasa ingin tahu yang tinggi membuat Satria mencari tahu tentang transportasi online GRAB yang sedang booming pada saat itu. Menggunakan GRAB sejak tahun 2016,dan pertama kali mengetahui transportasi online (GRAB) dari media sosial (handphone) dan televisi.

Pelayanan GO-JEK yang sering digunakan oleh Satria adalah grab-bike dan grab-food. Alasan beliau sering menggunakan pelayanan tersebut karena sangat praktis.

Satria memaparkan bahwa persepsinya terhadap transportasi online (GRAB) adalah GRAB memiliki harga yang transparant, jujur, dan konsisten. Walaupun kondisi jalan raya sedang padat, harga tidak mengalami perubahan. Pengalaman buruk dimasa lalu saat menggunakan transportasi konvensional menjadi alasan utama Satria lebih memilih 
INOBIS: Jurnal Inovasi Bisnis dan Manajemen Indonesia

Volume 2, Nomor 1, Desember 2018

Ratna Tri Hardaningtyas

menggunakan transportasi online GRAB.

Beliau mengungkapkan bahwa yang menjadi kelebihan GRAB terletak pada aplikasi yang dimiliki GRAB. Apabila pelayanan yang diberikan pengemudi kepada pelanggan dirasa kurang memuaskan maka dapat melakukan pengaduan dan penilaian terhadap pengemudi melalui aplikasi GRAB. Pengaduan dan penilaian kepada pengemudi, akan direspon dengan cepat dan ditindak oleh pihak manajemen PT GRAB Indonesia, serta pemberian sanksi terhadap pengemudi apabila pengemudi terbukti melakukan kesalahan yang merugikan konsumen. Sejauh ini saudara Satria belum pernah merasakan kekurangan dari transportasi online (GRAB).

\section{Zulvia, 31 tahun, dokter gigi}

Menggeluti profesi sebagai dokter gigi dan juga ibu rumah tangga, menjadikan Ibu Zulvia sebagai wanita yang super sibuk. Memiliki 2 buah hati di usia pertumbuhan, membuat Ibu Zulvia memutar otak bagaimana caranya untuk memastikan seluruh kebutuhannya agar terpenuhi. Menggunakan transportasi online (GRAB) sejak tahun 2016 dan pertama kali mengetahui GRAB dari media sosial dan media cetak (koran).

Menurut Ibu Zulvia yang menjadi kelebihan GRAB terletak pada berbagai macam pelayanan yang dimiliki GRAB. Namun, Ibu Zulvia mengungkapkan bahwa kekurangan GRAB terletak pada aplikasinya, pada saat Ibu Zulvia melakukan pemesanan tertera di aplikasi para pengemudi tidak berada didekat Ibu Zulvia. Menurut jarak yang ditempuh, pengemudi terkadang jauh dari lokasi Ibu Zulvia berada. Sehingga Ibu Fitria harus bersabar menunggu pengemudi tersebut datang.

\section{Rizky Adhi Nugraha, 26tahun, Customer Service BNI}

Informan berikut ini bernama Rizky dan berumur 26 tahun yang berprofesi sebagai Customer Service di BNI Life yang berlokasi di Basuki Rahmat Malang. Beliau menggunakan transportasi online (GRAB) sejak tahun 2016 dan pertama kali mengetahui GRAB dari sosial media (handphone) media cetak (Koran) dan rekan se profesinya.

Menurut Rizky yang menjadi kelebihan GRAB terletak pada harganya yang terjangkau. Namun beliau juga memaparkan beberapa hal yang menjadi kekurangan GRAB sehingga perlu ditinjau kembali oleh pihak manajemen GRAB terkait dengan standarisasi pengemudinya. Seperti standarisasi kendaraan mulai dari kelengkapan kendaraan pengemudi, seperti ban, sepeda motor yang digunakan, pengecekan mesin dan performa sepeda motor secara berkala.

\section{Nike Anggraini, 40 tahun, Ibu Rumah Tangga}

Wanita yang kerap dipanggil Ibu Nike adalah ibu rumah tangga yang memiliki keingin tahuan tinggi dan gemar mengikuti sesuatu yang sedang trend, Beliau menggunakan transportasi online (GRAB) sejak tahun 2017 karena rasa keingin tahuan beliau terhadap GRAB. Pertama kali mengetahui GRAB dari putrinya yang bernama Nadia, dan disitulah awal Ibu Nike memutuskan untuk mendownload aplikasi tersebut.

Pelayanan GRAB yang sering digunakan beliau adalah grab-car, grab-express, grab food dan grab-bike. Alasan beliau serng menggunakan pelayanan tersebut karena apabila Ibu Nike tidak memiliki waktu untuk berpergian membeli makanan, maka grab-food adalah alternatif yang sangat membantu disaat Ibu Nike membutuhkan makanan.

Menurut Ibu Nike yang menjadi kelebihan GRAB terletak pada segi keamanan, GRAB saat ini telah bekerjasama dengan Allianz, sebuah perusahaan yang bergerak dibidang asuransi. Ibu Nike mengungkapkan bahwa hal ini adalah sebuah perpaduan yang sangat 
INOBIS: Jurnal Inovasi Bisnis dan Manajemen Indonesia

Volume 2, Nomor 1, Desember 2018

Ratna Tri Hardaningtyas

cerdas dan menjadi salah satu kelebihan GRAB. Menggabungkan GRAB dengan asuransi kecelakaan diri dari Allianz. Setiap orang membutuhkan asuransi kecelakaan diri, termasuk para driver GRAB dan pelanggan. Beliau merasa lebih aman dan tenang menggunakan GRAB dengan adanya perlindungan asuransi kecelakaan diri dari Allianz. Serta GRAB sangat menomor satukan kebersihan para kosumennya, yaitu dengan menyediakan masker agar tidak terkenan debu, serta penutup kepala agar rambut tidak bercampur dengan rambut yang lain mengingat helm pelanggan hanya ada satu. Sejauh ini Ibu Nike belum pernah merasakan kekurangan dari transportasi online (GRAB).

\section{Abey, 28 tahun, Owner Cafe Tweenty First Coffee}

Informan kali ini adalah Abey, Owner Cafe Tweenty Coffee. Lelaki yang kerap disapa Mas Abey ini adalah pengguna transportasi online (GRAB). Beliau menggunakan transportasi online (GRAB) sejak tahun 2016 karena rasa keingin tahuan beliau terhadap GRAB yang saat itu sedang booming. Pertama kali mengetahui GRAB dari keluarga dan temannya.

Pelayanan GRAB yang sering digunakan beliau adalah grab-express, grab-food, grabbike. Alasan beliau sering menggunakan pelayanan tersebut karena mudah dan harganya terjangkau.

Menurut Abey yang menjadi kelebihan GRAB terletak pada harga yang terjangkau karena GRAB selalu memberikan promo-promo serta pelayanan yang beragam. Beliau mengaku, sejauh ini merasakan kekurangan GRAB pada saat menggunakan pelayanan grabbike. Kendaraan roda dua yang digunakan pengemudi saat itu sedang mengalami kebocoran pada bannya. Sehingga beliau harus menunggu lama hingga ban pengemudi selesai ditambal, belum ada kebijakan ganti rugi dari pihak manajemen GRAB terkait masalah ini.

\section{Mima, 39 tahun, Manager BNI Life}

Informan berikut ini bernama Ibu Mima. Beliau menggunakan transportasi online (GRAB) sejak tahun sejak tahun 2016 dan mengetahui pertama kali dari rekan se profesi di kantornya.

Pelayanan GRAB yang sering digunakan beliau adalah grab-bike, grab-food, grab-car dan grab-share. Alasan beliau sering menggunakan aplikasi tersebut karena harganya sangat terjangkau.

Menurut beliau, kinerja pengemudi GRAB pada saat beliau menggunakan pelayanannya adalah sangat baik. Sabar dan ramah dalam pelayanan yang dilakukan pengemudi kepada Ibu Mima menjadikan beliau senang menggunakan GRAB.

Menurut Ibu Mima yang menjadi kelebihan GRAB terletak pada promo harga yang terjangkau dan transparant. Sebelum pemesanan dilakukan, beliau dapat mengecek harga promo sebelum menggunakan transportasi GRAB. Namun Ibu Mima juga memaparkan kekurangan dari GRAB yang terletak pada standarisasi kendaraan pengemudi. Pada saat itu beliau menggunakan pelayanan grab-bike, pengemudi menggunakan sepeda motor merek Supra dengan tahun kendaraan dibawah standarisasi yang sudah ditetapkan, yaitu dibawah tahun 2010. Beliau berharap pihak manajemen GRAB untuk lebih memperhatikan standarisasi kendaraan pengemudi.

\section{Christian Arden, 23 tahun, karyawan swasta}

Lelaki yang kerap disapa Christian ini menggunakan transportasi online sejak tahun 2016, pertama kali mengetahui transportasi online (GRAB) dari keluarga dan media sosial (handphone).

Pelayanan GRAB yang sering digunakan beliau adalah grab-bike dan grab-food. Alasan 
INOBIS: Jurnal Inovasi Bisnis dan Manajemen Indonesia

Volume 2, Nomor 1, Desember 2018

Ratna Tri Hardaningtyas

beliau sering menggunakan pelayanan tersebut karena harganya yang terjangkau.

Christian memaparkan persepsinya terhadap transportasi online (GRAB) adalah pelayanan yang sangat membantunya dalam melakukan aktivitas sehari-hari.Karena pekerjaannya yang sibuk menjadikan Christian tidak memiliki waktu untuk membeli makanan. Dengan hadirnya layanan grab-food kini Christian tidak khawatir lagi, karena grabfood akan mengantarkan makanan yang di inginkan oleh beliau dilokasi manapun makanan itu berada dan masih di area Malang. Pemilihan menu makanan pun beragam di dalam aplikasi GRAB, mulai makanan India, Korea dan masih banyak lainnya. Harga makanan pun tertera di aplikasi tersebut. Sungguh menarik bukan? Hanya dengan satu aplikasi saja mampu memenuhi beragam kebutuhan konsumen. Menurut Christian transportasi online (GRAB) sangat membantu kesehariannya, tidak hanya bermanfaat bagi dirinya sendiri, Christian memaparkan bahwa hadirnya GRAB sangat membantu masyarakat untuk memenuhi perekonomian dengan bergabung menjadi mitra GRAB untuk menjadi pengemudi GRAB. Menurutnya, hal tersebut dapat membantu pemerintah utnuk mengurangi pengangguran.

\section{Lily, 35 tahun, karyawan swasta}

Bagi Ibu Lily, dirinya dan transportasi online adalah sesuatu yang tidak dapat dipisahkan. Kesibukannya yang menyita waktu membuatnya bergantung sepenuhnya pada layanan GRAB. Beliau menggunakan transportasi online (GRAB) sejak tahun 2016. Pertama kali mengetahui GRAB dari keluarga dan temannya.

Pelayanan GRAB yang sering digunakan beliau adalah grab-bike, dan grab-food. Namun hampir seluruh layanan GRAB pernah digunakan oleh Ibu Lily. Alasan beliau sering menggunakan pelayanan tersebut karena mudah, cepat dan harganya yang terjangkau.

Ibu Lily memaparkan persepsinya terhadap transportasi online (GRAB) adalah kemudahan dalam menggunakan aplikasi GRAB. Sistem pemesanan berbasis aplikasi, sehingga cocok dengan masyarakat di era modern yang menggunakan smartphone. Para pengemudinya dapat dipertanggung jawabkan, karena didalam aplikasi terdapat layanan pemberian rating kinerja pengemudi yang telah mengantar konsumen. Ratingnya dimulai dari 1-5, serta adanya kolom komentar jika keluhannya perlu diutarakan. Maka saat itu juga oleh pihak GRAB akan diproses, apabila pengemudi sangat merugikan konsumen, akan ditindak tegas oleh manajemen GRAB dengan memberhentikan pengemudi tersebut.

\section{Akbar, 18 tahun, Mahasiswa Universitas Brawijaya}

Mahasiswa yang menjadi informan kali ini bernama Akbar, beliau memaparkan bahwa memakai aplikasi GRAB sejak tahun 2016 dan mengetahui pertama kali GRAB dari teman, media sosial, televisi dan keluarga.

Pelayanan GRAB yang sering digunakan beliau adalah grab-bike, grab-food dan grabexpress. Alasan beliau sering menggunakan pelayanan tersebut karena pemesanannya yang mudah dan harga yang terjangkau.

Beliau memaparkan persepsinya terhadap transportasi online (GRAB) adalah mudah, cepat, aman dan hemat. Aplikasi pemesanan yang mudah, menjadikan saudara Akbar semakin senang dengan GRAB, walaupun banyaknya transportasi online yang sedang muncul, tetapi tidak ada yang semenarik GRAB.

Menurut beliau yang menjadi kelebihan GRAB terletak pada kemudahan penggunaan aplikasi. Terutama grab-food, aplikasi layanan pesan antar makanan. Harganya yang terjangkau juga menjadi alasan utama saudara Akbar untuk memilih GRAB dan tidak memerlukan tawar-menawar. Menurut saudara Akbar kekurangan GRAB terletak pada standarisasi kendaraan, sadel sepeda motor pengemudi sedikit rusak dan bengkok sehingga 
INOBIS: Jurnal Inovasi Bisnis dan Manajemen Indonesia

Volume 2, Nomor 1, Desember 2018

Ratna Tri Hardaningtyas

beliau merasa kurang nyaman pada saat menggunakan pelayanan grab-bike.

\section{Pembahasan}

Persepsi masyarakat sangat berpengaruh terhadap GRAB, dari persepsi masyarakat akan diketahui manfaat yang didapatkan saat menggunakan jasa transportasi GRAB, keuntungan apa saja yang didapatkan masyarakat saat menggunakan pelayanan, dan fasilitas yang didapatkan oleh masyarakat.

Dalam penelitian ini, peneliti menangkap bahwa pengaruh brand awareness bersignifikan positif terhadap persepsi masyarakat di Malang. Ciri khas yang menjadi faktor kesuksesan GRAB sehingga menjadi transportasi pilihan masyarakat di Indonesia yang hingga kini menjadi best choice online transportation. Warna hijau pada jaket dan helm pengemudi, promo-promo disetiap pekan, berbagai grab-rewards yang bias ditukarkan serta merk GRAB yang mudah di ingat oleh masyarakat di Malang. Kesuksesan GRAB dalam menentukan ciri khas mereka berdampak positif pada brand image. Salah satunya adalah warna hijau menyala dan merk GRAB yang membuat masyarakat di Malang mengenali dengan jelas bahwa itu adalah transportasi online yang menjadi best choice online transportation di Malang. Hal tersebut didukung dari hasil wawancara kepada responden yang bernama Abey dengan usia 28 tahun dan berprofesi sebagai owner cafe twenty first coffee dan responden yang bernama Ibu Icha dengan usia 31 tahun dan berprofesi sebagai ibu rumah tangga. GRAB sukses menerapkan brand awareness terhadap produknya sehingga calon pembeli/konsumen mampu mengenali dan mengingat mereknya.

Tidak hanya itu saja, peneliti juga melihat adanya pengaruh USP (Unique Selling Proporsition) yang diterapkan GRAB kepada produk dan layanannya juga sukses dilihat dari kemampuan para konsumen untuk membedakan GRAB dengan transportasi lainnya. Beragamnya pelayanan yang dimiliki serta pemesanan melalui aplikasi, menjadikan GRAB berbeda dengan transportasi online lainnya. Hampir seluruh informan mengaku bahwa mereka senang dengan pelayanan yang ditawarkan oleh GRAB karena nama pelayanan yang unik serta mudah untuk diingat.

Peneliti melihat bahwa masyarakat di Malang semakin modern hal tersebut didukung dari responden yang menggunakan smartphone. Masyarakat di Malang open minded terhadap hal baru. Tidak membuangnya mentah-mentah tetapi menggunakannya dan menerimanya. Peneliti menyimpulkan bahwa dalam melakukan marketing lebih efektif melalui media elektronik yang terletak dalam aplikasi GRAB. Respon positif transportasi online sangat melekat didalam benak masyarakat di Malang sebagai pengguna GRAB, bahwa transportasi tersebut memiliki aplikasi, dinaungi diperusahaan, promo harga yang transparan, dan pelayanan yang beragam.

\section{Simpulan dan Saran}

\subsection{Simpulan}

Berdasarkan penelitian dapat disimpulkan bahwa persepsi masyarakat terhadap transportasi online di Malang (GRAB) sangat positif. Masyarakat dari berbagai macam usia, latar belakang dan profesi, mereka mempunyai persepsi yang sama terhadap transportasi online (GRAB). Menurut peneliti, di era globalisasi dan modern, bila sesuatu perusahaan tidak hanya jasa saja, seluruh perusahaan bila tidak didukung dengan teknologi yang canggih maka akan ketinggalan dan bisnis yang dibangun tidak akan maju. Demikian dengan 
INOBIS: Jurnal Inovasi Bisnis dan Manajemen Indonesia

Volume 2, Nomor 1, Desember 2018

Ratna Tri Hardaningtyas

transportasi online yang menggunakan media elektronik disetiap pelayanannya. GRAB mampu membaca peluang serta mengikuti zaman. Mengingat GRAB sebagai perantara antara konsumen dan pengemudi.

Pelayanan yang beragam, harga yang transparant dan promo serta aplikasi yang dimiliki adalah salah satu faktor utama yang disenangi oleh masyarakat di Malang. Ciri khas dan merek yang melekat pada benak masyarakat menjadi kesuksesan GRAB dalam menanamkan persepsi di masyarakat, bahwa transportasi online adalah GRAB, kata yang mudah di ingat serta warna hijau yang mampu membuat masyarakat merekamnya dalam ingatan mereka.

Adanya asuransi kejiwaan yang diberikan GRAB kepada pengemudi dan penumpang. Menjadikan GRAB sebagai transportasi online yang memiliki tanggungjawab penuh terhadap keselamatan pengemudi maupun penumpang yang menggunakan pelayanan grab-bike.

Standarisasi kendaraan juga menjadi faktor penting yang dapat mempengaruhi persepi konsumen. Kondisi kendaraan pengemudi, mulai dari ban, mesin serta atribut seperti spion harus lebih diperhatikan. Peneliti menyimpulkan bahwa manjemen GRAB seharusnya selalu melakukan pengecekan standarisasi kendaraan pengemudi secara berkala, tidak hanya pada saat pengemudi melakukan pendaftaran, pengecekan standarisasi secara berkala juga dilakukan pada saat pengemudi bergabung menjadi mitra GRAB Mengingat selama ini setelah menjadi mitra GRAB, pengemudi melakukan pengecekan standarisasi kendaraan secara pribadi. Pengecekan standarisasi kendaraan pengemudi seharusnya berada dibawah pengawasan menejemen GRAB karena menyangkut keselamatan.

Kelengkapan atribut pengemudi perlu ditinjau kembali seperti jas hujan. Peneliti mengungkapkan bahwa jas hujan menjadi faktor penting untuk pelayanan grab-bike. Sejauh ini pengemudi dibebankan secara pribadi oleh GRAB untuk kelengkapan atribut jas hujan. Belum adanya ganti rugi kepada konsumen apabila pengemudi tidak membawa jas hujan.

Peneliti juga menyimpulkan permasalahan yang terjadi disini adalah faktor open minded yang harus diusung setiap pelaku bisnis, membaca peluang yang ada serta memanfaatkan teknologi yang tersedia. Hal tersebut diterapkan oleh perusahaan GRAB sehingga mampu menjadi transportasi online yang digemari oleh masyarakat di Malang.

\subsection{Saran}

Berdasarkan pada kesimpulan yang ada, penulis dapat memberikan saran-saran sebagai berikut: (1) bagi pihak trasnportasi online (GRAB) untuk meperhatikan standarisasi kendaraan pengemudi; (2) melakukan pengecekan secara berkala kepada kendaraan pengemudi maupun atribut kendaraan; (3) tidak membebankan secara pribadi pengecekan berkala kepada pengemudi, melainkan hal tersebut menjadi tanggungjawab pihak manajemen GRAB; (4) memberikan pilihan alternatif seperti mengganti rugi dengan nominal tertentu atau mengganti dengan pengemudi yang baru apabila kendaraan pengemudi mengalami masalah, seperti ban bocor. Hal seperti inilah yang belum diterapkan oleh manajemen GRAB; (5) memperhatikan kinerja pengemudi dengan melakukan pengecekan secara berkala serta melakukan pembinanaan, sehingga akan tercipta keharmonisan dalam perusahaan dan kinerja pengemudi dapat meningkat; (6) menambahkan pemilihan jenis sepeda motor yang diinginkan konsumen pada apliaksi GRAB. Apakah konsumen ingin menggunakan sepeda motor berjenis matic atau manual. Hal tersebut berpengaruh bagi kenyamanan kosumen; (7) melengkapi atribut pengemudi seperti jas hujan, dengan tidak membebankan secara pribadi kepada pengemudi; (8) melakukan ganti rugi maupun pemilihan alternatif kepada konsumen yang dirugikan karena pengemudi tidak membawa jas hujan; (9) menindaklanjuti pengemudi yang tidak membawa jas hujan agar pengemudi tidak lalai dikemudian hari. 
INOBIS: Jurnal Inovasi Bisnis dan Manajemen Indonesia

Volume 2, Nomor 1, Desember 2018

Ratna Tri Hardaningtyas

\section{Daftar Referensi}

Aaker, A. D. 1996. Manajemen Equitas Merek. Spectrum Mitra Utama. Jakarta. 1991. Managing Brand Equity: Capitalizing on the value of a brand name. The Free Press. New York.

Basu, S. 2005. Asas-asas Marketing. Liberty. Yogyakarta.

Bilson,S. 2001. Memenangkan Pasar dengan Pemasaran Efektif dan Profitabel. Edisi pertama. PT. Gramedia Pustaka Utama. Jakarta.

Boyd, H. 2000. Manajemen Pemasaran. Edisi Kedua. Jakarta.

Charles,W. 2001. Pemasaran. Edisi Pertama, Salemba Empat. Jakarta.

Creswell. 2010. Definisi Kualitatif. Erlangga. Jakarta.

Downey. 2002. Manajemen Agribisnis. Buku Keempat. Jakarta.

Hidayat. 2012. Strategi Memasarkan Produk Jasa. Jurnal Ilmiah Progressif 9(25): 112-140. Kotler, P and G. Armstrong. 2012. Prinsip-prinsip Pemasaran. Edisi13. Jilid 1. Erlangga. Jakarta.

. 2012. Strategi Merek. PT. Prenhallindo. Jakarta.

. dan K. L Keller. 2009. Manajemen Pemasaran. Edisi Ketiga Belas. Jilid 1. Erlangga. Jakarta.

Nafisa, N.M. 2015. Kepuasan Jasa Transportasi Online di Surabaya. Skripsi. Program Studi Manajemen Fakultas Ekonomi Universitas Negeri Surabaya. Surabaya.

Pawito. 2008. Penelitian Komunikasi Kualitatif. PT LKIS Pelangi Aksara. Yogyakarta.

Payne, A. 2001. The Essence Of Service Marketing. Andi dan Pearson Education (Asia) Pte.Ltd. Yogyakarta.

Robbins, S. P. 2001. Perilaku Organisasi. Edisi 8. Prentice Hall. Jakarta.

Rofiq,A. 2007. Pengaruh Dimensi Kepercayaan (trust) Terhadap Partisipasi Pelanggan Ecommerce . Studi Pada Pelanggan E-Commerce Di Indonesia. Skripsi. Program Studi Manajemen Fakultas Ekonomi Universitas Brawijaya. Malang.

Slameto. 2010. Persepsi Masyarakat. PT. Rineka Cipta. Jakarta.

Sugiyono. 2010. Analisis Kualitatif. Alfabeta. Bandung. 2012. Metode Penelitian Kuantitatif Kualitatif dan R dan B. Alfabeta. Bandung.

Susanto dan Wijanarko. 2004. Power Branding: Membangun Merek Unggul dan Organisasi Pendukungnya. PT. Mizan Publika. Jakarta.

Wahyuningtyas. 2016. Pengaruh Persepsi Kemudahan Terhadap Niat Beli Ulang Dengan Persepsi Kegunaan Sebagai Variabel Intervening (Studi Pada Pengguna Layanan Aplikasi GO-JEK di Surabaya). Jurnal Ekonomi Pemasaran 1 (1) (2016).

Walgito,B. 2000. Bimbingan dan Konseling (Studi dan karier) : Andi Offset. Yogyakarta.

Yue. 2010. Faktor-Faktor Yang Mempengaruhi Persepsi Masyarakat. Jakarta. 